\title{
XPO1 wt Allele
}

National Cancer Institute

\section{Source}

National Cancer Institute. XPO1 wt Allele. NCI Thesaurus. Code C99485.

Human XPO1 wild-type allele is located in the vicinity of 2p15 and is approximately $61 \mathrm{~kb}$ in length. This allele, which encodes exportin-1 protein, is involved in the modulation of nuclear transport. 